\title{
HUBUNGAN SKOR SOFA DENGAN MORTALITAS PADA PASIEN SAKIT KRITIS
}

\author{
Efris Kartika Sari ${ }^{\star 凶}$, Yati Sri Hayati ${ }^{\star}$, Nila Lestari Rokhmawati*
}

\begin{abstract}
Abstrak
Sepsis merupakan suatu kondisi yang berisiko meningkatkan morbiditas dan mortalitas pasien sakit kritis. Gugus Tugas Sepsis-3 merekomendasikan Skor Sequential (Sepsis-related) Organ Failure Assessment (SOFA) untuk mengidentifikasi kondisi sepsis pada pasien sakit kritis. Penelitian ini bertujuan untuk mengetahui hubungan skor SOFA dengan mortalitas pasien sakit kritis di ruang rawat intensif Rumah Sakit dr. Saiful Anwar Malang. Penelitian ini merupakan penelitian kohort retrospektif yang menggunakan data sekunder berupa rekam medik pasien. Skor SOFA dihitung pada saat pasien masuk ke ruang rawat intensif. Sejumlah 115 rekam medik yang lengkap yaitu memenuhi kebutuhan perhitungan skor SOFA dianalisis. Hasil penelitian menunjukkan nilai rata-rata skor SOFA pasien adalah $7,25 \pm 3,85$, dengan mortalitas pasien di ruang rawat intensif sebesar $55,6 \%$. Uji statistik menunjukkan perbedaan yang bermakna antara skor SOFA pasien yang hidup dan yang meninggal $(p<0,05)$, dan ada hubungan antara skor SOFA dengan mortalitas $(p<0,05)$. Disimpulkan bahwa skor SOFA saat pasien masuk berhubungan dengan mortalitas pasien sakit kritis di ruang rawat intensif.
\end{abstract}

Kata kunci: mortalitas, pasien sakit kritis, skor SOFA

\section{THE CORRELATION BETWEEN SOFA SCORE AND MORTALITY OF CRITICALLY ILL PATIENTS}

\begin{abstract}
Sepsis is a condition that can increase the risk of morbidity and mortality of critically ill patients. The Sepsis-3 Task Force recommends the use of the Sequential (Sepsis-related) Organ Failure Assessment (SOFA) score for the identification of sepsis in critically ill patients. This study aimed to determine a correlation between SOFA score and mortality of critically ill patients in the intensive care unit (ICU) of dr Saiful Anwar Hospital Malang. This study was a retrospective cohort using secondary data in the form of medical records. The SOFA score was calculated when the patient was recently admitted into ICU. A total of 115 medical records that met the criteria were analyzed. The results showed the mean SOFA was $7.25 \pm 3.85$ points, and ICU mortality was $55.6 \%$. Statistical analysis demonstrated a significant difference in SOFA scores of patients who lived and died $(p<0.05)$, and any relationship between SOFA score and ICU mortality $(p<0.05)$. It is concluded that admission SOFA score was correlated with ICU mortality of critically ill patients.
\end{abstract}

Keywords: critically ill patients, mortality, SOFA score

*Jurusan Keperawatan, Fakultas Kedokteran, Universitas Brawijaya

E-mail: efriskartika@ub.ac.id 


\section{Pendahuluan}

Sepsis merupakan kondisi disfungsi organ yang mengancam nyawa akibat disregulasi respons tubuh terhadap infeksi. ${ }^{1}$ Diperkirakan lebih dari 30 juta orang di dunia mengalami sepsis, dengan potensi mortalitas sebesar 6 juta orang per tahun. Surviving Sepsis Campaign 2012 menyebutkan tingkat mortalitas pasien sepsis sekitar $41 \%$ di Eropa dan $28,3 \%$ di Amerika Serikat. ${ }^{2}$ Selanjutnya, berdasarkan data yang diperoleh dari ruang rawat intensif Rumah Sakit (RS) dr. Saiful Anwar Malang mulai bulan Januari tahun 2018 sampai dengan bulan April tahun 2019, diketahui sebagian besar pasien yang dirawat di ruang rawat intensif $(>50 \%)$ mengalami infeksi, dengan kasus terbesar adalah pneumonia, yang kemudian berkembang menjadi sepsis. Tingkat kematian pasien dengan sepsis tersebut $50 \%$ lebih tinggi daripada pasien yang tidak mengalami sepsis.
Tingginya angka mortalitas pasien sepsis menjadi alasan perlunya identifikasi segera untuk menentukan metode pengobatan yang tepat dan efektif sehingga meningkatkan kesembuhan pasien. ${ }^{3}$ Konsensus tentang sepsis yaitu Sepsis-3 merekomendasikan The Sequential (sepsisrelated) Organ Failure Assessment (SOFA) untuk mengidentifikasi disfungsi organ pada pasien sakit kritis yang diduga mengalami infeksi. ${ }^{4,5}$ Komponen penilaian SOFA meliputi enam sistem organ utama, yaitu pernapasan, renal, hepar, hematologi, sistem saraf pusat, dan kardiovaskular (Tabel 1). Kondisi disfungsi ogan direpresentasikan oleh peningkatan nilai total skor SOFA $\geq 2 .{ }^{1}$

Skor SOFA total yang tinggi (SOFA maksimum) dan perubahan/perbedaan SOFA yang tinggi (SOFA maksimum total dikurangi SOFA total saat masuk) diketahui berhubungan dengan outcome yang lebih buruk pada pasien. ${ }^{7}$

Tabel 1. Skor Sequential Organ Failure Assessment (SOFA) ${ }^{6}$

\begin{tabular}{|c|c|c|c|c|c|}
\hline \multirow{2}{*}{ Sistem Organ } & \multicolumn{5}{|c|}{ Skor SOFA } \\
\hline & 0 & 1 & 2 & 3 & 4 \\
\hline $\begin{array}{l}\text { Pernapasan, } \mathrm{PaO}_{2} / \mathrm{F}_{i} \mathrm{O}_{2} \text {, } \\
\mathrm{mmHg}(\mathrm{kPa})\end{array}$ & $\geq 400(53,3)$ & $<400(53,3)$ & $<300(40)$ & $\begin{array}{l}<200(26,7) \\
\text { dengan } \\
\text { bantuan } \\
\text { pernapasan }\end{array}$ & $\begin{array}{l}<100(13,3) \\
\text { dengan } \\
\text { bantuan } \\
\text { pernapasan }\end{array}$ \\
\hline $\begin{array}{l}\text { Koagulasi, Platelet, } \\
x 10^{3} / \mathrm{mm}^{3}\end{array}$ & $\geq 150$ & $<150$ & $<100$ & $<50$ & $<20$ \\
\hline $\begin{array}{l}\text { Hepar, Bilirubin, } \\
\text { mg/dL }\end{array}$ & $<1,2$ & $1,2-1,9$ & $2,0-5,9$ & $6,0-11,9$ & $>12,0$ \\
\hline Kardiovaskular & $\begin{array}{l}M A P \geq 70 \\
m m H g\end{array}$ & $\begin{array}{l}\mathrm{MAP}<70 \\
\mathrm{mmHg}\end{array}$ & $\begin{array}{l}\text { Dopamin } \\
<5 \text { atau } \\
\text { dobutamin } \\
\text { (dalam } \\
\text { dosis } \\
\text { berapapun) }\end{array}$ & $\begin{array}{l}\text { Dopamin } \\
5,1-15 \text { atau } \\
\text { epinephrine } \\
\leq 0,1 \text { atau } \\
\text { norepine- } \\
\text { phrine } \leq 0,1\end{array}$ & $\begin{array}{l}\text { Dopamin } \\
>15 \text { atau } \\
\text { epinephrine } \\
>0,1 \text { atau } \\
\text { norepine- } \\
\text { phrine }>0,1\end{array}$ \\
\hline $\begin{array}{l}\text { Sistem Saraf Pusat, } \\
\text { Skor Glasgow Coma } \\
\text { Scale (GCS) }\end{array}$ & 15 & $13-14$ & $10-12$ & $6-9$ & $<6$ \\
\hline $\begin{array}{l}\text { Renal, Kreatinin, } \mathrm{mg} / \mathrm{dL} \text {, } \\
\text { urine output, } \mathrm{mL} / \mathrm{hari}\end{array}$ & $<1,2$ & $1,2-1,9$ & $2,0-3,4$ & $\begin{array}{l}3,5-4,9 \\
<500\end{array}$ & $\begin{array}{l}>5,0 \\
<200\end{array}$ \\
\hline
\end{tabular}

Keterangan: Dosis katekolamin $\mu \mathrm{g} / \mathrm{kg} /$ menit selama paling tidak 1 jam. $\mathrm{F}_{i} \mathrm{O}_{2}$ : fraksi oksigen inspirasi; MAP: mean arterial pressure; $\mathrm{PaO}_{2}$ : tekanan parsial oksigen; Skor total berkisar antara 0-24 
Studi terdahulu menunjukkan skor SOFA yang dihitung saat pasien baru masuk ke ruang rawat intensif, dan perubahan skor SOFA yang dihitung pada hari ke 1-7 berhubungan dengan mortalitas pasien baik di ruang rawat intensif maupun di rumah sakit (in-hospital mortality). ${ }^{8,9}$ Studi lain menyatakan pasien dengan skor SOFA awal $<7$ memiliki angka mortalitas 56\%, dan meningkat menjadi $70 \%$ pada pasien dengan skor 8-15. Skor tersebut dikaji ulang setelah 48 jam, hasilnya pasien dengan skor SOFA $<7$ memiliki angka mortalitas $52 \%$ dan meningkat menjadi $88 \%$ pada skor $8-15 .{ }^{10}$

Meskipun skor SOFA digunakan untuk menggambarkan dan mengukur fungsi organ tubuh, dan tidak dimaksudkan untuk memprediksi outcome, namun studi terdahulu menunjukkan hubungan antara terjadinya disfungsi organ dengan mortalitas pasien. Oleh karena itu, penelitian ini bertujuan untuk mengetahui hubungan skor SOFA awal dengan mortalitas pasien sakit kritis yang dirawat di ruang rawat intensif $R S d r$. Saiful Anwar Malang.

\section{Bahan dan Metode}

\section{Desain Penelitian}

Desain penelitian ini adalah observasional analitik yaitu kohort retrospektif. Penelitian ini menggunakan sampel berupa rekam medik pasien yang dirawat di ruang rawat intensif RS dr. Saiful Anwar Malang selama periode bulan Juni - Agustus tahun 2019. Variabel bebas dalam penelitian ini adalah skor SOFA, sedangkan variabel terikatnya adalah mortalitas pasien sakit kritis. Kriteria inklusi penelitian ini adalah: 1) pasien berusia $>18$ tahun, 2) pasien diduga atau terkonfirmasi mengalami infeksi. Kriteria eksklusi penelitian ini adalah: 1) rekam medik tidak lengkap/tidak memenuhi kebutuhan perhitungan skor SOFA. Penelitian ini telah mendapatkan keterangan laik etik dari Komisi
Etik Penelitian Kesehatan RSUD dr. Saiful Anwar (No. 400/185/K.3/302/2019).

\section{Prosedur Penelitian}

Rekam medik yang memenuhi kriteria penelitian akan diidentifikasi skor SOFA pasien yang dihitung pada saat pasien masuk ke ruang rawat intensif, yaitu dalam rentang waktu 24 jam setelah masuk. Skor SOFA total berkisar antara 0-24. Penilaian skor SOFA meliputi enam sistem organ utama, yaitu yaitu pernapasan ( $\mathrm{PaO} 2 / \mathrm{FiO} 2)$, renal (kreatinin), hepar (bilirubin), hematologi (platelet), neurologi (GCS), dan kardio-vaskular (MAP). Penilaian setiap organ tersebut berkisar dari nilai nol (0) yang berarti fungsinya normal sampai nilai empat (4) yang dinilai sangat abnormal, sehingga total penilaian akan berkisar antara $0-4$. Selanjutnya, mortalitas diidentifikasi sebagai kematian pasien selama dirawat di ruang rawat intensif.

\section{Analisis Statistik}

Data penelitian yaitu skor SOFA disajikan sebagai nilai rata-rata \pm standar deviasi (SD), sedangkan mortalitas pasien dalam bentuk persentase. Perbandingan skor SOFA pasien yang hidup dan yang meninggal diuji dengan Mann-Whitney $U$ test. Hubungan skor SOFA dengan mortalitas diuji dengan Chi-Square test. Hasil uji statistik dianggap bermakna apabila didapatkan nilai $p<0,05$.

\section{Hasil}

Jumlah rekam medik yang memenuhi kriteria untuk dianalisis dalam penelitian ini adalah 115. Karakteristik demografi subjek penelitian disajikan dalam Tabel 2. Jumlah skor SOFA pasien pada saat masuk ruang rawat intensif yang berkisar 0-24 disajikan dalam Gambar 1. Sebagian besar pasien tersebut mengalami kondisi disfungsi multiorgan pernapasan dan sistem saraf pusat (Tabel 3). 
Nilai rata-rata skor SOFA pasien adalah $7,25 \pm 3,85$, dengan nilai rata-rata skor SOFA pasien yang meninggal $(8,63 \pm 3,55)$ lebih tinggi secara signifikan daripada pasien yang hidup $(5,47 \pm 3,11)$ (Mann-Whitney $U$ test, $p<$ $0,05)$.

Tabel 2. Karakteristik demografi

\begin{tabular}{llc}
\hline \multicolumn{1}{c}{ Karakteristik } & $\mathrm{n}$ & Persentase (\%) \\
\hline Usia (Tahun) & & \\
$\quad<25$ & 17 & 14,8 \\
$26-45$ & 38 & 33,0 \\
$45-65$ & 60 & 40,0 \\
$\quad>67$ & 14 & 12,2 \\
Jenis kelamin & & \\
$\quad$ Laki-Laki & 50 & 43,5 \\
$\quad$ Perempuan & 65 & 56,5 \\
Kasus penyakit & & \\
$\quad$ Medikal & 50 & 43,5 \\
$\quad$ Bedah & 65 & 56,5 \\
Riwayat penyakit kronis & & \\
$\quad$ Ada & 75 & 65,2 \\
$\quad$ Tidak & 40 & 34,8 \\
\hline
\end{tabular}

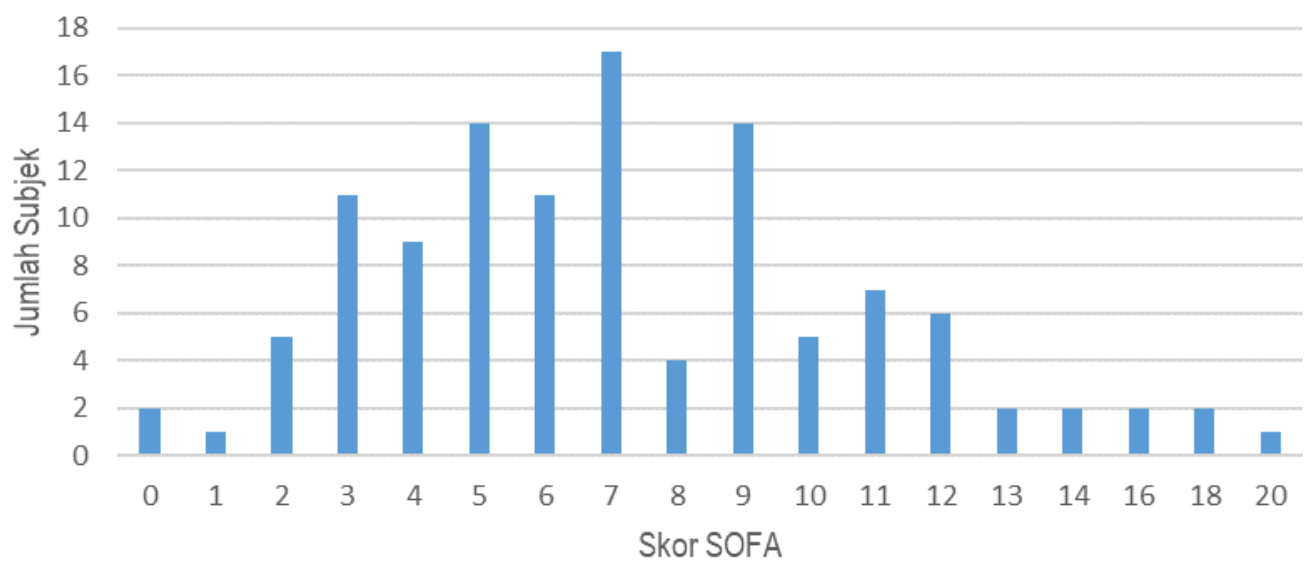

Gambar 1. Jumlah skor SOFA pasien pada saat masuk ruang rawat intensif

Tabel 3. Kondisi disfungsi multi organ yang dialami pasien

\begin{tabular}{lc}
\hline \multicolumn{1}{c}{ Disfungsi Organ } & Persentase (\%) \\
\hline Pernapasan + sistem saraf pusat & 26,2 \\
Pernapasan + sistem saraf pusat + kardiovaskular & 19 \\
Pernapasan + sistem saraf pusat + kardiovaskular + renal & 12 \\
Pernapasan + sistem saraf pusat + kardiovaskular + renal + & 12 \\
koagulasi & 9,5 \\
Pernapasan + sistem saraf pusat + renal & 7,1 \\
Pernapasan + koagulasi + kardiovaskular & 7,1 \\
Sistem saraf pusat + koagulasi + renal & 7,1 \\
Pernapasan + sistem saraf pusat + kardiovaskular + renal + & koagulasi + hepar \\
\hline
\end{tabular}


Jumlah mortalitas pasien di ruang rawat intensif adalah 64 pasien (55,6\%). Beberapa kelompok pasien dengan skor SOFA 8, 12, 13, 14, 18, dan 20 memiliki persentase mortalitas $100 \%$ (Gambar 2). Kemudian, skor
SOFA pasien dikategorikan $<7$, dan $\geq 7$ dan dihubungkan dengan mortalitas (Tabel 4). Uji statistik menunjukkan hubungan antara skor SOFA tersebut dengan mortalitas pasien (Chi -Square test, $p<0,05$ ).

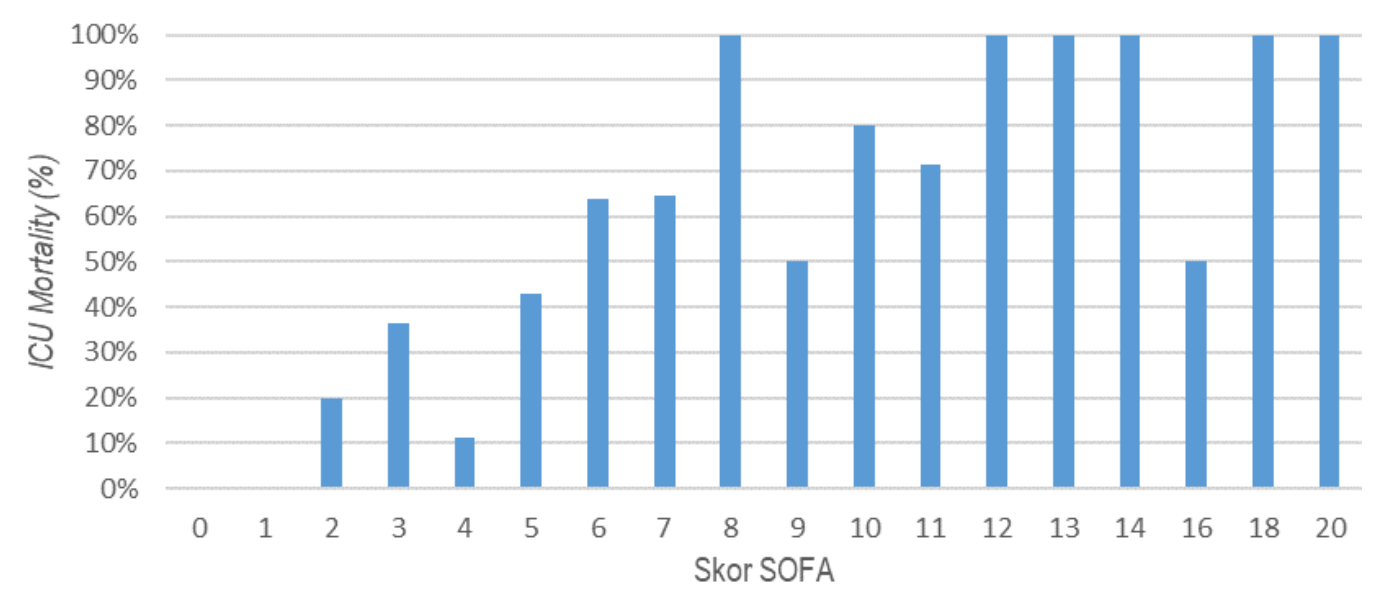

Gambar 2. Skor SOFA pasien yang mengalami mortalitas

Tabel 4. Hubungan skor SOFA dengan mortalitas

\begin{tabular}{|c|c|c|c|c|c|c|c|}
\hline \multirow{3}{*}{ Skor SOFA } & \multicolumn{4}{|c|}{ Mortalitas } & \multicolumn{2}{|c|}{ Total } & \multirow{3}{*}{ Nilai $p$} \\
\hline & \multicolumn{2}{|c|}{$\mathrm{Ya}$} & \multicolumn{2}{|c|}{ Tidak } & \multirow{2}{*}{$n$} & \multirow{2}{*}{$\%$} & \\
\hline & $n$ & $\%$ & $n$ & $\%$ & & & \\
\hline$<7$ & 19 & 35,8 & 34 & 64,2 & 53 & 100 & \\
\hline$\geq 7$ & 45 & 72,6 & 17 & 27,4 & 62 & 100 & $0,000^{*}$ \\
\hline Total & 64 & 55,7 & 51 & 44,3 & 115 & 100 & \\
\hline
\end{tabular}

Keterangan: $\mathrm{Cl} 95 \%,\left({ }^{*}\right)=0,05$.

\section{Pembahasan}

Data penelitian menunjukkan hampir seluruh pasien (97\%) yang menjadi subjek penelitian mengalami infeksi dengan disfungsi organ (sepsis), yaitu memiliki skor SOFA $\geq 2$, dengan nilai rata-rata $7,25 \pm 3,85$. Sebagian besar pasien tersebut (40\%) berada pada rentang usia $45-65$ tahun, dan $65,2 \%$ pasien memiliki riwayat penyakit kronis sebagai kondisi komorbid. Pada pasien usia lanjut yang disertai kondisi komorbid terjadi penurunan fungsi fisiologis sehingga meningkatkan risiko terjadinya disfungsi organ dan prognosis yang buruk. ${ }^{11}$

Persentase mortalitas pasien di ruang rawat intensif adalah $55,6 \%$. Nilai rata-rata skor SOFA pasien yang meninggal lebih tinggi daripada pasien yang hidup, dan hasil uji statistik memperlihatkan perbedaan nilai rata-rata skor SOFA tersebut signifikan. Semakin tinggi skor SOFA mengindikasikan meningkatnya jumlah dan keparahan disfungsi organ pada pasien. Hasil tersebut sesuai dengan studi terdahulu yang menunjukkan bahwa pasien dengan skor SOFA tinggi memiliki risiko lebih tinggi mengalami mortalitas. ${ }^{10,} 12$

Hasil identifikasi skor SOFA memperlihatkan sebagian besar pasien yang meninggal mengalami disfungsi multiorgan, yaitu pernapasan, sistem saraf pusat, kardiovaskular, dan renal. Kondisi inflamasi yang meluas akibat infeksi telah menyebabkan abnormalitas pada berbagai sistem organ..$^{13}$ 
Penilaian sistem pernapasan melalui $\mathrm{PaO} 2 /$ $\mathrm{FiO} 2$ merupakan indikator pasien mengalami acute respiratory distress syndrome (ARDS). Pasien dengan ARDS mengalami penurunan compliance paru dan hipoksemia refrakter yang menyebabkan tidak terpenuhinya kebutuhan oksigenasi jaringan tubuh secara adekuat. ${ }^{14}$ Selain itu, pada sistem neurologi penurunan skor Glasgow Coma Scale (GCS) berbanding lurus dengan penurunan tingkat kesadaran pasien dan keparahan cedera pada otak. Penurunan skor GCS tersebut berhubungan dengan peningkatan risiko perburukan dan mortalitas pada pasien. ${ }^{15}$ Kemudian, penilaian organ kardiovaskular adalah mean arterial pressure (MAP) pasien, yang merupakan variabel penting pada pengelolaan pasien dengan sepsis. The Surviving Sepsis Guidelines merekomendasikan target MAP awal pada pasien yang mendapat terapi vasopresor adalah $65 \mathrm{mmHg}$ untuk meraih perfusi jaringan yang optimal. Hipotensi yang berkepanjangan (nilai MAP $<65 \mathrm{mmHg}$ ) berhubungan dengan peningkatan mortalitas pada pasien. ${ }^{16}$ Selanjutnya, peningkatan kreatinin serum merupakan penanda terjadinya cedera ginjal akut (acute kidney injury/AKI) pada pasien sepsis. Akibatnya terjadi penurunan kemampuan filtrasi dan eliminasi hasil metabolisme nitrogen yang terjadi secara progresif, biasanya terjadi selama beberapa jam sampai beberapa hari setelah onset sepsis. Kenaikan kadar kreatinin serum dikaitkan dengan hasil luaran pasien yang lebih buruk. ${ }^{17,}, 18$

Berdasarkan hasil penelitian diketahui pasien dengan skor SOFA $\geq 7$ angka mortalitasnya sebesar $72,6 \%$ yaitu lebih tinggi dibandingan dengan pasien yang memiliki skor SOFA $<7$ yaitu $35,8 \%$. Kemudian, uji statistik menunjukkan ada hubungan antara skor SOFA dengan mortalitas pasien. Hal tersebut sesuai dengan hasil penelitian Iskandar dan Siska (2020), yang menyatakan pasien dengan skor SOFA $\geq 7$ memiliki kemungkinan 3,8 kali lipat lebih besar pasien untuk meninggal dibandingkan dengan pasien yang memiliki skor SOFA $<7.12$ Hasil penelitian lain yaitu oleh Bale et al. juga menyatakan bahwa skor SOFA dapat digunakan sebagai prediktor outcome pasien. ${ }^{10}$

\section{Keterbatasan Penelitian}

Pada penelitian tidak dilakukan perhitungan skor SOFA secara serial sehingga belum diketahui peningkatan skor SOFA pasien dibadingkan saat awal masuk ruang rawat intensif.

\section{Kesimpulan}

Hasil penelitian ini menyatakan bahwa terdapat hubungan antara skor SOFA pasien saat masuk dengan mortalitas pasien di ruang rawat intensif. Saran untuk penelitian selanjutnya yaitu hendaknya melakukan perhitungan skor SOFA secara serial sehingga dapat memberikan gambaran lebih rinci tentang perubahan skor SOFA pasien, dan hubungannya dengan mortalitas.

\section{Daftar Pustaka}

1. Singer M, Deutschman CS, Seymour CW, et al. The Third International Consensus Definitions for Sepsis and Septic Shock (Sepsis-3). JAMA. 2016; 315(8):801-810.

2. Levy MM, Artigas A, Phillips GS, et al. Outcomes of the Surviving Sepsis Campaign in Intensive Care Units in the USA and Europe: A Prospective Cohort Study. Lancet Infect Dis. 2012; 12(12):919 $-924$.

3. Giamarellos-Bourboulis EJ, Tsaganos T, Tsangaris I, et al. Validation of the New Sepsis-3 Definitions: Proposal for Improvement in Early Risk Identification. Clinical Microbiology and Infection. 2017; 23:104-109.

4. Finkelsztein EJ, Jones DS, Ma KC, et al. Comparison of qSOFA and SIRS for 
Predicting Adverse Outcomes of Patients with Suspicion of Sepsis Outside the Intensive Care Unit. Critical Care 2017; 21(73):1-10.

5. Camm CF, Hayward G, Elias TCN, et al. Sepsis Recognition Tools in Acute Ambulatory Care: Associations with Process of Care and Clinical Outcomes in a Service Evaluation of an Emergency Multidisciplinary Unit in Oxfordshire. BMJ Open. 2018; 8:e020497.

6. Li Y, Yan C, Gan Z, et al. Prognostic Values of SOFA Score, qSOFA Score, and LODS Score for Patients with Sepsis. Ann Palliat Med 2020; 9(3):1037-1044.

7. Woude SWvd, Doormaal FFv, B.A. Hutten3 FJN, Holleman F. Classifying Sepsis Patients in the Emergency Department using SIRS, qSOFA or MEWS. The Netherlands Journal of Medicine. 2018; 76(4):158-166.

8. Karakike E, Kyriazopoulou E, Tsangaris I, Routsi C, Vincent J-L, GiamarellosBourboulis EJ. The Early Change of SOFA Score as a Prognostic Marker of 28 -Day Sepsis Mortality: Analysis Through a Derivation and a Validation Cohort. Crit Care. 2019; 23(387).

9. Soo A, Zuege DJ, Fick $\mathrm{GH}$, et al. Describing Organ Dysfunction in the Intensive Care Unit: a Cohort Study of 20,000 Patients. Crit Care 2019; 23(186).

10. Bale C, Kakrani AL, Dabadghao VS, Sharma ZD. Sequential Organ Failure Assessment Score as Prognostic Marker in Critically III Patients in a Tertiary Care Intensive Care Unit. Int J Med Public Health 2013; 3:155-158.
11. Esper AM, Moss M, Lewis CA, Rachel Nisbet M, David, M. Mannino M, and Greg S. Martin, MD, MSc. The Role of Infection and Comorbidity: Factors that Influence Disparities in Sepsis. Crit Care Med. 2006; 34(10):2576-2582.

12. Iskandar A, Siska F. Analisis Hubungan Sequential Organ Failure Assessment (SOFA) Score dengan Mortalitas Pasien Sepsis. Jurnal Kesehatan Andalas. 2020; 9(2):168-173.

13. Sari EK, Wihastuti TA, Ardiansyah W. Probiotik Meningkatkan Konsentrasi Hemoglobin pada Tikus Putih yang Diinduksi Lipopolisakarida Escherichia coli. Majalah Kesehatan. 2018;5(1):18-25.

14. Bakhtiar A, Maranatha RA. Acute Respiratory Distress Syndrome. Jurnal Respirasi 2018; 4(2):51-60.

15. Mahdian M, Fazel MR, Fakharian $E$, Akbari H, Mahdian S. Cerebral State Index Versus Glasgow Coma Scale as a Predictor for In-Hospital Mortality in BrainInjured Patients. Chin J Traumatol 2014; 17(4):220-224.

16. Leone $M$, Asfar $P$, Radermacher $P$, Vincent J-L, Martin C. Optimizing Mean Arterial Pressure in Septic Shock: a Critical Reappraisal of the Literature. Critical Care. 2015; 19(101).

17. Dellinger RP, Levy MM, Rhodes A, et al. Surviving Sepsis Campaign: International Guidelines for Management of Severe Sepsis and Septic Shock: 2012. Crit Care Med. 2013;41:580-637.

18. Setiawan D, Harun H, Azmi S, Priyono D. Biomarker Acute Kidney Injury (AKI) pada Sepsis. Jurnal Kesehatan Andalas. 2018;7 (Supplement 2). 